\title{
Pendidikan Kesehatan Pengaruh Gadget Terhadap Remaja
}

\author{
Rodiyah Soekardi ${ }^{1}$ Theresia Puspitawati2 ${ }^{*}$ Nur Avira Pasca Wati \\ 1,2,3 Program Studi Kesehatan Masyarakat Fakultas Ilmu Kesehatan Universitas Respati Yogyakarta \\ Jl. Raya Tajem Km 1,5, Maguwoharjo, Depok, Sleman 55281 Telp 02744437888 \\ Email: rodiyahsoekardi@gmail.com \\ DOI: $10.18196 / \mathrm{ppm} \cdot 34.276$
}

\begin{abstract}
Abstrak
Gadget memberi kemudahan banyak hal. Namun gadget juga membawa dampak negatif. Keterikatan pada gadget akan menyebabkan remaja kurang mampu untuk merespon yang terjadi sekitarnya sehingga akan mengganggu dalam bersosialisasi. Remaja merupakan satu fase pertumbuhan dan perkembangan baik secara fisik, psikis maupun intelektual. Sifat khas remaja adalah mempunyai rasa ingin tahu, menyukai tantangan dan berani menanggung risiko tanpa didasari pertimbangan yang matang. Oleh karena itu, diperlukan upaya untuk meningkatkan kesadaran, pengetahuan dan keterampilanremaja dalam mengakses internet secara sehat dan aman. Pendidikan kesehatan ini bertujuan untuk meningkatkan pengetahuan remaja mengenai dampak positif dan negatif gadget dan upaya pencegahan dampak negatif. Pendekatan menggunakan contextual learning dengan metode interaktif. Sasaran kegiatan ini adalah remaja di Desa Hargobinangun, Pakem,Sleman, DIY. Materi pendidikan meliputi pengertian gadget, dampak positif dan negatif gadget serta upaya untuk mencegah efek negatif gadget. Kegiatan diikuti oleh 18 peserta dengan mayoritas berjenis kelamin perempuan dalam rentang usia 15 -19 tahun dengan pendidikan SMA/MAN/SMK. Hasil Uji Wilcoxon diperoleh $P ; 0,001(a<0,05)$ sehingga dapat disimpulkan bahwa ada perbedaan tingkat pengetahuan tentang gadget sebelum dan sesudah penyuluhan.
\end{abstract}

Kata Kunci: pendidikan, gadget, negatif, remaja

\section{Pendahuluan}

Jumlah masyarakat Indonesia yang mengakses internet mencapai 150 juta jiwa tersebar diseluruh wilayah. Pengguna internet mobile berjumlah 142.8 juta jiwa dengan persentase penetrasi sebesar 53\% (https://aptika.kominfo.go.id, 2020). Sedangkan waktu akses internet per hari penduduk Indonesia mencapai delapan jam 36 menit, jam untuk main media sosial, dua jam melihat video, satu jam streaming musik. Selebihnya untuk bisnis dan akses informasi lainnya (berita atau pendidikan) (https://www.boc.web.id, 2020).

Teknologi membantu manusia untuk melakukan hal-hal lebih efisien. Kemajuan teknologi perangkat komputer telah berevolusi sehingga kita bisa menggenggam komputer di tangan. Kehidupan kita telah berubah dengan adanya gadget (https://scet.berkeley.edu, 2020).

Teknologi menghasilkan kemudahan dalam segala bidang termasuk termasuk komunikasi (Wajszczyk (2014). Dampak positif gadget antara lain memfasilitasi interaksi jarak jauh, termasuk belajar secara online. Informasi tentang topik yang diperlukan, berlatih melalui kuis online maupun, tutorial online kini mudah diperoleh. Anak-anak dan remaja bisa mengasah keterampilan kognitif dan motorik bisa terasah melalui beberapa aplikasi permainan. Anakanak dan remaja lebih kompetitif karena berada pada lingkungan yang penuh persaingan (Dhendhe, 2019).

Namun demikian beberapa penelitian menunjukkan gadget juga membawa dampak negatif, masyarakat semakin individualistis (Sa'adah, 2015). Gagdet juga berdampak terhadap perkembangan emosional anak. Ketergantungan pada gadget bisa berdampak pada tumbuh kembang. Ketika kecanduan gadget, maka anak atau remaja akan membatasi kemampuan dalam berkomunikasi dan bersosialisasi. Tidak mampu untuk mengenali emosi, seperti simpati, sedih, atau senang. Keterikatan pada gadget juga menyebabkan anak kurang mampu untuk 
merespon apa yang terjadi sekitarnya sehingga akan mengganggu bersosialisasi dengan lingkungan sekitarnya (Riza, 2016).

Gadget juga berpotensi menimbulkan depresi dan masalah kesehatan mental pada masa kanak-kanak dan remaja. Hal ini akan berdampak pada terganggunya karakter (Sundus, 2018). Remaja dalam proses pencarian jati diri, teknologi dan paparan informasi yang sedemikian deras bisa berdampak negatif pada individu termasuk persepsi citra tubuh yang mengalami distorsi, perilaku seksual berisiko, kemudahan mengakses pornografi, komersialisasi, risiko obesitas dan menurunkan prestasi akademik (Dhendhe, 2019).

Remaja merupakan satu fase pertumbuhan dan perkembangan pesat secara fisik, psikis maupun intelektual. Sifat khas remaja adalah mempunyai rasa keingintahuan yang besar, menyukai tantangan dan berani menanggung risiko tanpa didasari pertimbangan yang matang (INFODATIN, 2016). Internet telah menjadi bagian yang tidak dapat dipisahkan dari kehidupan sehari-hari anak-anak dan remaja di Indonesia. Oleh karena itu, diperlukan upaya-upaya untuk meningkatkan kesadaran, pengetahuan dan keterampilan mereka dalam berinternet sehat dan aman. Hal ini dapat dicapai melalui sosialisasi, pendidikan literasi maupun pelatihan. (https://kominfo.go.id, 2020).

\section{Metode Pelaksanaan}

Pendidikan kesehatan ini bertujuan untuk meningkatkan pengetahuan remaja Hargobinangun mengenai dampak menggunakan gadget yang berebihan yang meliputi pengertian, nilai positif dan dampak negatif penggunaan gadget dan upaya pencegahannya. Pendekatan pendidikan kesehatan menggunakan contextual learning dengan metode interaktif dengan peserta. Sasaran keegiatan ini adalah remaja atau warga usia dewasa di Desa Hargobinangun, Pakem, Sleman, DIY.

Materi pendidikan meliputi pengertian gadget, positif gadget, dampak negatif penggunaan gadget serta upaya-upaya yang dapat dilakukan untuk mencegah efek negatif gadget dengan menggunakan gadget secara bijaksana. Kegiatan dilakukan di Balai Desa Hargobinangun Pakem, Sleman. Partisipasi mitra adalah dengan menyediakan fasilitas pendukung kegiatan.

Pelaksana pengabdian masyarakat memiliki kompetensi yang sesuai dengan permasalahan mitra. Kompetensi Tim Pengabdian: Pengabdi pertama memiliki kompetensi di bidang Promosi Kesehatan, Perubahan Perilaku, Penguatan Kapasitas. Pengabdi kedua memiliki komptensi di bidang Promosi Kesehatan, Media Promosi Kesehatan, Pengorganisasian dan Pengembangan Masyarakat. Pengabdi ketiga memiliki komptensi di bidang Epidemiologi, Biostatistik dan Surveilans Kesehatan Masyarakat

\section{Hasil dan Pembahasan Karakteristik responden}

Tabel 1 menunjukkan bahwa mayoritas peserta berjenis kelamin laki-laki yakni 14 orang (77,78\%) dengan mayoritas pada rentang usia 15-19 tahun (50\%). Tingkat pendidikan terbanyak SMA/MAN/SMK sejumlah 10 orang $(55,56 \%)$ dan status pekerjaan mayoritas adalah pelajar/mahasiswa 13 orang $(72,22 \%)$. 


\begin{tabular}{rlcc}
\hline NO & Variabel & Pretest & Posttest \\
\hline 1. & Skor Terendah & 5 & 9 \\
\hline 2. & Skor tertinggi & 13 & 13 \\
\hline 3. & Rata-rata & 9 & 11,17 \\
\hline 4. & P value & 0,001 & \\
\hline \multicolumn{4}{c}{ Sumber: Data Primer (2019) }
\end{tabular}

\section{Hasil Analisis Pretest dan Posttest}

Tabel 2. Hasil Pretest dan Posttest Pendidikan Kesehatan tentang Bahaya Gadget bagi Anak dan Remaja

\begin{tabular}{|c|c|c|c|}
\hline No & Variabel & $\mathrm{N}$ & $\%$ \\
\hline 1 & $\begin{array}{l}\text { Jenis kelamin } \\
\text { Perempuan } \\
\text { Laki-laki }\end{array}$ & $\begin{array}{r}14 \\
4\end{array}$ & $\begin{array}{l}77,78 \\
22,22\end{array}$ \\
\hline 2 & $\begin{array}{l}\text { Umur } \\
\text { 15-19 tahun } \\
\text { 20-24 tahun } \\
\text { > } 24 \text { tahun }\end{array}$ & $\begin{array}{l}9 \\
8 \\
1\end{array}$ & $\begin{array}{c}50,00 \\
44,44 \\
5,56\end{array}$ \\
\hline 3 & $\begin{array}{l}\text { Pendidikan } \\
\text { SMP } \\
\text { SMA/MAN/SMK } \\
\text { S1 }\end{array}$ & $\begin{array}{r}2 \\
10 \\
6 \\
\end{array}$ & $\begin{array}{l}11,11 \\
55,56 \\
33,33 \\
\end{array}$ \\
\hline 4 & $\begin{array}{l}\text { Pekerjaan } \\
\text { Tidak bekerja } \\
\text { Pelajar/mahasiswa } \\
\text { Ibu rumah tangga } \\
\text { Karyawan }\end{array}$ & $\begin{array}{r}2 \\
13 \\
1 \\
2\end{array}$ & $\begin{array}{c}11,11 \\
72,22 \\
5,56 \\
11,11\end{array}$ \\
\hline & Jumlah & 18 & 100,00 \\
\hline
\end{tabular}

Sumber: Data Primer (2019)

Jumlah peserta penyuluhan 18 orang, maka diasumsikan data tidak terdistribusi normal sehingga analisis untuk dua kelompok berpasangan dilakukan dengan Uji Wilcoxon dan diperoleh nilai p: 0,001 $(a<0,05)$. Hal ini menunjukkan bahwa terdapat perbedaan bermakna tingkat pengetahuan tentang gadget sebelum dan sesudah penyuluhan.

Tabel 2 menunjukkan peningkatan skor terendah 5 pada pretest menjadi 9 pada posttest sementara, pada skor tertinggi tetap sama pada pretest posttest yaitu 13. Skor rerata terdapat kenaikan dari 9 pada pretest menjadi 11,17 pada posttest. Hasil uji statistik didapatkan $\mathrm{p}$ value: 0,001 artinya secara statistik ada pengaruh penyuluhan tentang bahaya gadget bagi anak dan remaja.

\section{Pembahasan}

Sebagian besar peserta penyuluhan berjenis kelamin perempuan. Menurut Sarwono (2015) perempuan lebih bersifat sosial dan lebih mudah terpengaruh,. Karakteristik perempuan yang mudah terpengaruh perlu mendapat perhatian. Faktor "mudah terpengaruh" akan berdampak buruk apabila informasi tidak disaring. 
Mayoritas peserta berusia 15-19 tahun. Usia ini merupakan usia remaja. Sebuah masa transisi yang bisa mengakibatkan terjadinya kegoncangan (Willis, 2017). Hal ini terjadi karena remaja sedang dalam proses pendewasaan diri, belum sepenuhnya mampu mengelola emosinya sehingga sering tidak stabil secara emosional yang berdampak pada hubungan sosialnya (Fatimah, 2008). Kondisi ini memungkinkan untuk "lari" kepada gadget daripada berdiskusi orang tua. Oleh karena itu remaja harus dibekali pengetahuan yang cukup mengenai gadget sehingga akan membantu untuk tetap aman online (Dendhe, 2019).

Mayoritas peserta berstatus siswa atau pelajar yang menempuh pendidikan menengah. Pendidikan di tingkat menengah ini bertujuan menyiapkan peserta didik menjadi anggota masyarakat yang memiliki kemampuan mengadakan hubungan timbal balik dengan lingkungan sosial budaya dan alam sekitar serta dapat mengembangkan kemampuan lebih lanjut dalam dunia kerja atau pendidikan tinggi (https://ilmupendidikan.net, 2020) . Hal ini sejalan dengan status peserta yang berusia remaja dan perlu pendampingan. Orang tua dan guru adalah sosok pendamping yang ideal saat anak/remaja melakukan aktivitas kehidupan setiap hari. Deteksi dini permasalahan akan mencegah munculnya masalah yang lebih berat (Fatimah, 2008). Oleh karena itu, hubungan yang harmonis antara orang tua dan remaja dan guru dengan siswanya yang masih remaja menjadi sangat penting. Orang tua juga perlu mempunyai pengetahuan dan memahami dari aspek psikologi tentang perilaku anak-anak dan remaja. Orang tua juga perlu mengenal aplikasi atau game yang digemari remaja sehingga bisa mendampingi dengan bijaksana (Dhendhe, 2019).

Nilai-nilai agama dan akhlak amat penting untuk menjadi benteng kehidupan dalam menghadapi pengaruh negatif dari sekitar (Willis, 2017 hal 9). Hal ini berkaitan dengan aspek moral dalam kehidupan sosial seorang remaja (Sarwono, 2015). Notoatmodjo (2012) mengatakan bahwa kelompok pelajar adalah komunitas yang siap menerima pengetahuan atau inovasi. Secara psikologis para pelajar pergi ke sekolah memang untuk belajar jadi mentalnya sudah siap untuk menerima informasi baru. Hal ini sangt mendukung keberhasilan intervensi yang berupa pendidikan/penyuluhan. Jean Piaget dalam Fatimah, Enung (2010) kapasitas berpikir remaja usia sekolah secara logis dan abstrak telah berkembang sehingga mereka mampu berpikir multidimensi seperti ilmuwan. Para remaja pada usia ini, tidak lagi menerima informasi apa adanya, tetapi akan memproses informasi dan mengadaptasikannya dengan pemikiran mereka. kemampuan operasional formal para remaja akan mampu beradaptasi dengan lingkungan sekitarnya. Pengawasan orang tua sangat pentingkarena kemampuan adaptasi dengan lingkungan barunya yang belum tentu membawqa pengaruh positif dapat pula terjadi hal yang sebaliknya. Dalm hal penggunaan gadget pada remaja merupakan salah satu contoh konkrit adaptasi remaja pada lingkungannya (yang hampir semua menggunakan gadget). Meskuipun secara fisik remaja usia sekolah sudah sama dengan orang dewasa namun secara psikologis dan mental belum sepenuhnya dewasa sehingga pengawasan orang tua masih dibutuhkan.

Hasil skor rerata terdapat kenaikan dari 9 pada pretest menjadi 11,17 artinya naik dua poin pada posttest. Hasil uji statistik didapatkan pv. 0,001 artinya secara statistik ada pengaruh penyuluhan tentang bahaya gadget bagi remaja. Penyuluhan tentang bahaya gadget bagi remaja efektif meningkatkan pengetahuan masyarakat mengenai tentang dampak positif dan negatig gadget. Hal ini sesuai yang dikemukakan oleh Notoatmodjo, (2012) bahwa komunitas anak sekolah siap menerima informasi baru.

Hasil evaluasi peserta terhadap kegiatan penyuluhan, sebagian besar $(88,24 \%)$ menyatakan materi penyuluhan baik. Hal ini terjadi yang pertama berbicara tentang gadget adalah berbicara tentang dunia remaja (dunia para peserta) sehingga mereka 
merasa nyambung ketika mengikuti penyuluhan. Penggunaan alat bantu, 64,71\% mengatakan cukup. Penyuluhan ini menggunakan alat bantu pengeras suara, LCD, dan pointer. Untuk penyuluhan berikut disarankan dilengkapi dengan alat bantu atau media lain seperti leaflet dan lain-lain. Penyampaian materi 82,35\% mengatakan baik. Artinya, sebagian besar peserta tertarik dan memahami materi yang disampaikan dalam penyuluhan. Hal ini sejalan dengan hasil uji statistik yang menunjukan adanya peningkatan pengetahuan dari para peserta.

\section{Simpulan}

Hasil pendidikan kesehatan menunjukkan ada peningkatan pengetahuan setelah pelaksanaan pendidikan kesehatan. Hal ini trelihat dari:

1. Skor pretest terendah adalah 5 dan tertinggi adalah 13

2. Skor posttest terendah 9 dan tertinggi 13

3. Rata-rata pretest 9 dan posttest 11,17

4. Ada peningkatan pengetahuan peserta penyuluhan tentang gadget sebelum dan sesudah penyuluhan ( $p$ value: 0,001$)$

\section{Ucapan Terima Kasih}

Ucapan terima kasih penulis menyampaikan terima kasih kepada Kepala P3M UNRIYO, Dekan Fakultas Ilmu Kesehatan, Ketua Program Studi S-1 Kesehatan Masyarakat, Kepala Desa Hargobinangun, Pakem, Sleman, yang memfasilitasi terselenggaranya kegiatan pengabdian masyarakat, peserta penyuluhan Pendidikan kesehatan pengaruh gadget pada remaja, serta semua pihak yang yang telah membantu terlaksananya pengabdian masyarakat ini.

\section{Daftar Pustaka}

Dhende, T. R., 2019. The impact of using gadgets on children's psychology. International Journal of Applied Research 2019; 5(8): 157-160

Edberg, Mark. 2010 alih bahasa Anwar Hasan dkk. Buku Ajar Kesehatan Masyarakat: Teori Sosial dan Perilaku. Jakarta: EGC

https://aptika.kominfo.go.id/2019/08/penggunaan-internet-di-indonesia/ diakses 25 Oktober 2020

https://ilmu-pendidikan.net/pendidikan/peraturan/jenjang-pendidikan-formal-di-indonesia-uusisdiknas-2003 diakses 25 Oktober 2020

https://kominfo.go.id/content/detail/3834/siaran-pers-no-17pihkominfo22014-tentang-risetkominfo-dan-unicef-mengenai-perilaku-anak-dan-remaja-dalam-menggunakaninternet/0/siaran_pers diakses 25 Oktober 2020

https://scet.berkeley.edu/reports/gadget-addiction/ diakses 25 Oktober 2020

https://www.boc.web.id/statistik-pengguna-digital-dan-internet-indonesia-2019/ diakses 25

Oktober 2020

https://www.it-jurnal.com/pengertian-internet/ diakses 25 Oktober 2020

INFODATIN. 2016. Situasi Kesehatan Reproduksi Remaja. Pusat Data dan Informasi

Kementerian Kesehatan Republik Indonesia

Notoatmodjo, Soekidjo. (2010). Ilmu Perilaku Kesehatan. Jakarta: Rineka Cipta. 
Riza, L.U. 2016. Perkembangan Sosial Anak Usia Dini Pengguna Gadget. PSIKOSAINS, Vol.11, No.2, Agustus 2016, Hal. 82-98 ISSN : 1907-5235

Sa'adah. (2015). Dampak Penggunaan Gadget Terhadap Perilaku Sosial Siswa di MAN

Cirebon 1 Kabupaten Cirebon. Fakultas Ilmu Tarbiyah dan Keguruan Institut Agama Islam Negeri (IAIN) Syekh Nurjati Cirebon

Sundus, J. (2018). The impact of using gadget on children. Lahore Garrison University Journal of Depression and Anxiety, 7(1). DOI: 10.4172/2167-1044.1000296.

Wajszczyk, R. (2014). A study of the impact of technology in early education. (Unpublished thesis). Uppsala Universitet, Uppsala.

Willis, S 2012. Remaja dan Masalahnya. Penerbit Alfabeta , Bandung 